\title{
28 Research Square \\ Traditional usage of underutilized aquatic plants found in the Imphal valley of Manipur
}

Okram Abemsana Devi ( $\nabla$ okramabemsana@gmail.com )

Assam Agricultural University

Mridula Barooah Saikia

Assam Agricultural University

Sanjoy Singh Ningthoujam

Ghanapriya Women's College, Dhanamanjuri University

\section{Research Article}

Keywords: Traditional usage, Wetlands, aquatic plants, Manipur

Posted Date: December 30th, 2021

DOI: https://doi.org/10.21203/rs.3.rs-782178/v2

License: (1) This work is licensed under a Creative Commons Attribution 4.0 International License.

Read Full License 


\section{Abstract}

The paper focuses on the traditional usage of aquatic plants found in the wetland areas of the Imphal valley of Manipur. From the survey, 30 aquatic plants have been collected use for the management of various health conditions. Most of the collected plants consume as daily food items, some used for specic remedial purposes in the treatment of certain types of ailments and diseases like cough, fever, ulcer, piles, diarrhea, jaundice, skin diseases, rheumatic pain, diabetes, hypertension, urinary troubles, body pain, respiratory problems, urinary problems, cardiovascular diseases, etc. Accordingly, different parts of the plant are used as a single item or by mixing with other ingredients in various forms of fresh or raw, culinary, or as a tonic or dry or powder form to treat the diseases. The aquatic plants also incorporate in the preparation of various traditional dishes. $70 \%$ of collected wetland plants are marketable provides a means of livelihood and source of income for the poor and needy people. Therefore, proper documentation and preservation of traditional knowledge are essential that may provide useful for future generations through research in pharmaceuticals and drug discovery.

\section{Introduction}

Wetlands are 'wealthlands' or 'biological supermarkets' because of the extensive food chain and rich biodiversity that they support (Moirangleima 2007). They are one of the most biologically productive ecosystems on Earth and provide numerous services to human civilization (Ghermandi et al. 2011). Wetlands are lands transitional between terrestrial and aquatic systems (Cowardin et al. 2005) and consist of lakes, rivers, bogs marshes. It is the areas of land that remain waterlogged for a substantial period of the year. Wetlands in India comprise less than $5 \%$ of the total geographical region, and they are the most productive biomes that support one-fifth of the total biodiversity (SACONH, 2004), (Jain et al., 2011). The Indian landscape is prominent for 4290 large lakes and numerous small water bodies (Kumar and Dhankhar 2015), (Jain et al. 2011). Northeast India falls under Indo-Burma global hotspot, and the area harbors a maximum number of wetlands (Venkataraman and Sivaperuman 2018). Wetlands of northeast India have a rich diversity of habitats consists of lakes, reservoirs, bells, rivers, ponds, etc., and one of the most productive life-supporting systems having immense socio-economic and ecological importance to the people of the region(Convention 1990), (Chandra et al., n.d.). The Loktak Lake (Manipur), Deepor Beel (Assam), Rudrasagar (Tripura), Palak, and Tamdil (Mizoram) are a few of the freshwater wetlands of the region known for their resources (Chandra et al. 2018), (Chatterjee et al. 2006). Manipur is a state that consists of several lakes, marshes, swamps, canals $(24,804$ ha), rivers and streams $(13,888 \mathrm{ha})$, and low-lying wetlands (9,219 ha) that cover a total area of 47,911 ha. Among the 13 lakes (wetlands) found in Manipur, Loktak lake (42,672 ha) is the biggest and is one of the Ramsar sites of global significance (Ministry of Environment and Forests 2010) (Jain and Singh 2014). The maximum number of lakes is in Imphal and Thoubal districts. However, there are also several smaller lakes known as Kom (pits). In different areas of Manipur, there are around 134 waterlogged marshy and swampy wetlands. These areas are low-lying, situated either in the peripheral areas or the vicinity of the lakes. The maximum number of areas covered with water are recorded in the Imphal valley (69), followed 
by Thoubal (40) and Bishnupur districts (21). There are two artificial reservoirs, one each in Senapati and Tamenglong districts (Centre and Environment 2017), (ENVIS, 2015). More than 30 ethnic communities with a total population of about 23 lakhs, mainly dependent upon their cumulative knowledge and surrounding resources for their day-to-day healthcare, inhabit different parts of the state (Jain and Singh 2014). In addition to providing food and medicine, maintain the livelihood and income of an extensive segment of people living around them (Jain et al. 2011). Wetland is also very rich in medicinal plants that help in curing various ailments and diseases. Since time immemorial, the application of traditional medicine not only helps in conserving their traditional knowledge but also helps in the management of health and diseases. From this, we can say that the practice of ethnomedicine plays a vehicle for understanding indigenous societies and their relationship with nature. The rapid declined in usage, ignorance, changes in climate, environment, and advancement in pharmaceutical medicines have posed a threat to their practices. Hence, proper documentation of aboriginal knowledge is of utmost importance that we can achieve through ethnobotanical studies in the conservation and management of biological resources. The documentation of aquatic plants will facilitate future research on the safety and efficacy of different ailments. In addition, insufficient data are available specifically on ethnobotanical reports of aquatic plants in Manipur. And it is also revealed that aquatic plants have a higher concentration of bioactive compounds because of their ability to adjust in intense environmental conditions like alkaline, or acidic water, high or low temperature, high pressure, and inadequate substrate in the water (Baharum, Beng, and Mokhtar 2010), (Vijayan et al. 2012). It will facilitate the discovery of new sources of drugs and promote the sustainable use of aquatic plants. Therefore, considering these points, the present study is focused on the traditional usage of aquatic plants found in the Imphal valley of Manipur.

\section{Materials And Methods}

\section{Study Area}

Manipur is an isolated hill grit state lying in the extreme northeastern corner of India along the indoMyanmar border. The geographical area consists of about 22,327 square kilometers (8,621 sq mi) (Jain et al. 2011) and has a population density of 2,855,794 as per the 2011 census. Around 90 percent of the state consists of hilly regions; the remaining are by the lacustrine plains of the Central Valley (Singh and Moirangleima 2009). The present study area consists of wetlands areas situated in the Central or Imphal valley of Manipur $\left(93^{\circ} 42^{\prime}\right.$ to $94^{\circ} 11^{\prime} \mathrm{E}$ and $24^{\circ} 41^{\prime}$ to $25^{\circ} 06^{\prime} \mathrm{N}$ ). It is an intermundane basin around $70 \mathrm{~km}$ long (north to south) and 30-35 km wide (east to west), oval-shaped with an unequal outline covered by hills. The valley is a high flood plain with an altitude of around $760 \mathrm{~m}$ above mean sea level. Several streams and rivers arising from the hills are the main physiological features of the valley and many shallow wetlands and marshes in the interfluvial areas. The Imphal River is the most significant perennial river flowing in the Central Valley of Manipur and its tributaries (Iril, Thoubal, Khuga, Sekmai, Chakpi, etc.). Other small rivers (Nambul, Nambol, Kongba, Merakhong, etc.) dried out throughout the lean period (Moirangleima 2007), (Singh and Moirangleima 2009). 
The lacustrine plains of the Central Valley were the site of an ancient lake which was afterward filled up and uplifted to its current position, the remnant of which is the Loktak lake which occupies the south-east corner of the valley is the Loktak Lake (Singh, 1982). Several lakes are encircling on both sides of the Imphal River. The biggest river Loktak has stayed on the right side of the Imphal River; on the left side lays the Ikoppat/Kharungpat, Waithoupat, Khoidumpat, Lamjaopat, and Pumlenpat. Most of these lakes become contiguous throughout the rainy season (May to August), on the other hand, merged under a massive sheet of water during the dry season. All the smaller lakes Ikoppat/Kharungpat, Waithoupat, Utrapat, Poiroupat, Sanapat, Loushipat, and Ushoipokpipat are extremely aged eutrophic and seasonal marshy land areas (Moirangleima 2007).

\section{Methods}

The collection of data for the study has been done based on both primary and secondary sources. The data was accumulated through the primary sources by surveying all the wetlands and a comprehensive survey of Loktak and Pumlen lakes situated in the Central Valley of Manipur. To understand various utilization of the lakes features was collected through questionnaire interviews. The information regarding traditional usage was gathered through an extensive survey (2018-2019), semi-structured interviews, and focus group discussions. A total of 200 individuals (30-70 yrs) were questioned together with village chiefs, priests, senior leaders, local healers (Maibas and Maibis) identified with the assistance of local administrators and community leaders. Field visits involved direct contact with the community and also visiting the Ema market (local market), the nearest and hugest market in Manipur. At around 10-15 women vendors in the Ema market were catechized regarding the local name of the plants, uses, source, and medicinal properties. A few numbers of herbal practitioners/healers $(n=10)$ also visited. During the discussion, information was assembled based on vernacular names, plant parts used, mode of preparation, administration, and measured doses and documented elaborately for the medication of particular ailments. To obtain accurate data secondary sources of data from the published works on the aquatic plants of Manipur have also been consulted. Plant specimens secured after regular field trips to the wetlands of Manipur were identified as to their scientific names and families with the help of experts and using standard literature and floras (Jain, 2007), (Jain, 1968), (Singh et al., 2003), (Sinha, 1987), (Sinha, 1996). All the literature concerning the wetlands of the state has been interrelated. Efforts have been given to recover accurate data by touring several times for validation. Out of the 30 collected aquatic plants ten plants were estimated of their mineral content, such as calcium, magnesium, iron, and zinc, using standard methods (Rangana SC. 1979). The ten samples were washed thoroughly under running tap water to make them free from dust and then dried in a shady area at room temperature $\left(25^{\circ} \mathrm{C}\right)$ with regular turning. Dried plant parts were then chopped and ground to a coarse powder using an electronic grinder for laboratory analysis (who, 2003).

Considering community perception regarding plants use and taste, availability, and conservation status were aggregate for different aquatic plants using a random sampling method. The community interpretation ( $n=30$ ) was ranked on a range of 1 to 4 from least to highly preferred category. For assessing 'Use' and 'Taste' status the ranking was done with the community members as 4-most 
preferred, 3-commonly preferred, 2-preferred but not so common, and 1-occasionally used. For 'Availability' status the species was ranked based on field observations of the authors, market availability trend, and interaction with collectors and user groups as 4-extensively available, 3-commonly available, 2available but not so common, 1-rare. For 'Conservation' status, the scale ranked as 4-for the species whose conservation is highly needed, 3-conservation urgently needed, 2-conservation required but not so urgent, and 1-not required at present. Such ranking of the species found favor to understand community perception on the use of the species(Sundriyal and Sundriyal 2003).

\section{DATA ANALYSIS}

The mineral content of the ten aquatic plants is presented as average mean values $( \pm S D)$. The data collected on community ranking of aquatic plants for their use, taste, availability, and conservation status was qualitative, which ranked on a scale of 1 to 4 to convert it to quantitative form. The information was ethnographically analyzed based on community discernment, belief, and thoughts about aquatic plant resources so that the management and protection movements can be addressed in near future.

\section{Results}

The observations made and collected on traditional usage are presented (Table no.1) with botanical names of the plants arranged in alphabetical order followed by their families in parentheses and local names in the Manipuri language. Out of 30 aquatic plants accumulated from the wetland areas of the central valley of Manipur state, of which 21 plants adopted in the traditional delicacies such as ootti, eronba, singju, etc. All the aquatic plant species had a common name that explains the prevalent use of these species in the traditional system.

Most commonly consumed aquatic plants are Alocasia cuculata, Cyperus haspan, Enhydra fluctuans, Eryngium foetidum, Euryale ferox, Hedychium coronarium, Houttuynia cordata, Ipomea aquatic, Nelumbo nucifera, Neptunia oleraceae, Oenanthe javanica, Polygonum barbatum, Polygonum posumba, Sagittaria sagittifolia, Trapa natans, and Zizania latifolia. Diverse communities used different modes to consume these aquatic plants. Consumption in the form of raw was the most preferred mode to use these plants and incorporated in the most commonly eaten traditional preparation viz. ootti, eronba, singju, etc. The 'Singju' was prepared by aquatic plants along with fermented fish, chili, and other plants; eronba was made by boiling plant parts and smashing it with potatoes, chili, and fermented fish before consuming; while the only local dish, 'ootti' was prepared by boiling vegetables with a pinch of sodium bicarbonate (Table 2). At least one item of these traditional delicacies incorporates in an everyday meal becomes an indispensable constituent of the local diets, which explained the significance of these aquatic plants in the local food system.

A total of ten aquatic plants estimated for the mineral content has been presented in Table 3. Maximum and minimum content of iron was recorded in Jussiaea repens and Zizania latifolia; for magnesium in Trapan natas and Zizania latifolia; for calcium in Trapan natas and Zizania latifolia; and for zinc in Ipomea aquatica and Eleocharis dulcis, respectively (Table 3). 
Community matrix ranking of use status, taste preference, availability status, and conservation of 30 aquatic plants found in the wetland areas of the central valley of Manipur is presented in Table 4 and Figure 3A to 3D. From the use of species, 7 aquatic plant species were most preferred while 9 other commonly preferred (Table 4 Figure 3A). The most frequently used plant was Alocasia cuculata, Eryngium foetidum, Euryale ferox, Hedychium coronarium, Houttuynia cordata, Neptunia oleraceae, and Oenanthe javanica. Taste-wise 12 plants were highly preferred while another 4 plants were commonly preferred (Figure 3B). Availability status of the plant showed just one plant as extensive available and another 12 plants as commonly available (Figure 3C). Alocasia cuculata, Euryale ferox, Hedychium coronarium, Nelumbo nucifera, Neptunia oleraceae, and Zizania latifolia was extremely demanding due to their extensive utilize, intense collection, and market demand (Figure 3D). Considering the four ranking parameters, the most desired aquatic plant was Alocasia cuculata, Euryale ferox, Hedychium coronarium, Houttuynia cordata , Nelumbo nucifera, Neptunia oleracea, and Zizania latifolia (Table 4). Fascinating work that farmers have started cultivation of Alocasia cuculata, Eryngium foetidum, Euryale ferox, Houttuynia cordata, Ipomea aquatic, Neptunia oleracea, Nelumbo nucifera, Oenanthe javanica, Polygonum barbatum, and Polygonum posumba, at the household level.

\section{Discussion}

From the present study, 30 species belong to 24 families have been identified. The collected aquatic plants used in the healing of various diseases and ailments viz. cough, fever, headache, wounds, ulcer, piles, diarrhea, dysentery, jaundice, eye and skin diseases, rheumatic pain, diabetes, hypertension, urinary troubles, muscular and body pain, respiratory problems, urinary problems, cardiovascular diseases, bleeding, constipation, fracture of bones, gonorrhea, smallpox, measles, snakebite, etc. They use either orally/internally or externally. Orally in the form of tonic or concoction or as culinary, especially the fresh leaf or part of the plant used for curing of ailments such as stomach ache, headache, chronic ulcer, gastritis, etc. And externally in the form of ointment or pastes or balm for the cases of cuts, burn, sprang, fracture, septic, etc. The most frequent practice used for therapeutic purposes was to make paste, decoction, or powder, or to boil or eat raw. From the survey, it was discovered that most of the diseases viz. indigestion, dysentery, and intestinal infections (14 species); skin diseases (13 species); gout, muscular and rheumatic sprains (12 species); blood pressure and circulation problems (12 species); cough and fever (10 species); urinary troubles (9 species); diabetes (9 species); boils, burns, and wounds (7 species); earache and insect bites (6 species); stomach ulcers (6 species); jaundice ( 5 species); cuts and injuries (4 species); piles (4 species); paralysis (3 species); intestinal worms, leucoderma; food poisoning and cancer (1 each species) were treated with locally available aquatic plants. Among the plant parts used for medicinal purposes, leaves are the most commonly used (26\%), followed by young shoots $(20 \%)$, rhizome (14\%), and least by flower, tuber, stem consists of only $3 \%$ as shown in fig no 2 .

Local people consume rice as a staple item with green leafy vegetables and salad. The communities used diverse modes to devour these aquatic species. Their diet exclusively depends on the fresh green vegetables they eat. Consumption in the form of raw was the most preferred mode to utilize the aquatic plants and incorporated in the most commonly eaten traditional preparation such as ooti, eronba, singju, 
etc. Singju is the most prominent conventional food made by combining aquatic plants with fermented fish, chili, and other plants. Eronba is prepared by boiling plant parts and smashing them with potatoes, chili, and fermented fish; while ooti is prepared by boiling vegetables with a pinch of sodium bicarbonate (Table 2). At least one item in each feast was a crucial component of the local diets, which explained the significance of aquatic plants in the local system. Polygonum barbatum (yelang), Ipomea Aquatica (Komlamni), Oenanthe javanica (Komprek), Neptunia oleracea (Ekaithabi), Eurgale fero (Thangjing), Trapa natans (Heikak), Marsilea minuta (Ising ensang), Nelumbo nucifera (Thambou), Nymphaea alba (Tharo) are some of the aquatic plants used as remedial purposes but incorporated in the preparation of various traditional dishes such as Eronba, Singju, Kangsoi, Chamthong, Paknam, Ooti, etc.

The most common ten aquatic plant species estimated for different mineral content has been presented in Table 3. The maximum and minimum content of iron was recorded in Jussiaea repens and Nelumbo nucifera; for magnesium in Trapan natas and Eleocharis dulcis, for calcium in Trapan natas and Eleocharis dulcis; and for zinc in Ipomea aquatica and Eleocharis dulcis, respectively. From fig. 1, we can conclude that $70 \%$ of the plants are marketable, and the remaining $30 \%$ are non-marketable. Besides, most of the aquatic plants grow wild and are available in abundance. Consequently, people generously collect them and provides a means of livelihood and source of income specifically for the poor and landless people. Among aquatic plants, Cyperus haspan, Euryale Ferox, Ipomoea, Nelumbo nucifera, Neptunia oleraceae, Oenanthe javanica, Polygonum barbatum, Trapa natans, Sagittaria sagittifolia, Zizania latifolia, etc. are some of the common vegetables sold in the market of Manipur. And Sagittaria sagittifolia, Nelumbo nucifera, Neptunia oleraceae, Zizania latifolia, Cyperus haspan are some delicacies and expensive conventional foods available in Manipur. Most of the rural population was drawn into the business that primarily comprises womenfolk. Neptunia oleracea, Sagittaria sagittifolia, and Zizania latifolia are some of the most demanding aquatic species regardless of their inadequate availability which could lead to their constricted scope of distribution and accessibility during the growing season only. Some of the species viz. Euryale ferox, Colocasia esculenta, Oenanthe javanica, Nelumbo nucifera, Polygonum barbatum, Hedychium coronarium, and Sagittaria sagittifolia are also a way of generating incomes among the rural people. Above all, most of these plants are consumed uncooked with the belief that they obtain direct nutritional and medicinal benefit and thus incorporated in various conventional dishes viz. Eronba, Kangsoi, Chamfut, Ooti, Kangsu, Singju, Chagem-Pomba, etc.

Several wetlands are drying due to climatic conditions and transform into other landforms such as paddy fields, human settlements, a land modification for developmental, and indirectly by rainfall shift. It is suggested that a sturdily participatory approach is necessary for the sustainable management of wetland areas. To accomplish the said objective, the community needs to be well-thought-out for adopting sustainable harvest protocols for all the aquatic and wetland plants, and necessary training can be imparted for them. Additionally, appropriate value chain development for selling and value-addition for aquatic plants can bring good revenue to the communities. Thereby helps in soaring their income from them by improving keeping quality and developing by-products is very much necessary as the majority of the species have low self-life. Furthermore, aquatic plants can be grown in the fields by applying 
appropriate agro-techniques that will facilitate in management and conserving of aquatic plants in wetland areas. Therefore, prominence on identification, documentation, assessment of the patterns, validation of nutritional quality is crucial. In addition, the conservation of wetlands is becoming a globally discussed issue. Therefore, proper documentation and preservation of wetland plants help ensure sustainable, self-reliant socio-economic development of wetland areas by strengthening community linkages and acknowledging the aesthetic beauty of the place through ecotourism, etc. And, sustainable harvesting of aquatic plants can be approved to get long-term perspectives.

\section{Conclusion}

Interactions between researchers and locals people have not only brought understanding between local people and researchers but also their orally handling down traditional practices for the management of various disease ailments. Documentation and preservation of the traditional knowledge are challenges, still can be preserved for future pharmaceuticals and drug discovery with constant efforts on ethnobotanical surveys and analysis of the plants used by various ethnic communities. Therefore, a joint holistic approach between the researchers, NGOs, and locals peoples is necessary for the conservation and protection of such valuable treasure to enlarge the population of the threatened wetland plants in their natural habitat.

\section{Declarations}

\section{ACKNOWLEDGEMENT}

The authors are pleased to the entire ethnic community of Imphal valley for providing their valuable traditional usage and its practices on aquatic plants found in wetland areas of Manipur. This paper would not have been made possible without their kind-heartedness to share it with us. The authors are highly thankful to Forest Department of Manipur for their constant help and support.

\section{AUTHORS' CONTRIBUTIONS}

O.A.D and M.B.S conceived and conceptualized the research idea, designed the experiments, interpreted the results and prepared the manuscript. O.A.D carried out purposive sampling for aquatic plants with relation to community dependence for subsistence and organised interview schedules. O.A.D and M.B.S carried out mineral analysis of commonly used aquatic species. S.S.N helps in identifying the aquatic plants and participated in design and coordination of the study. All authors read and approved the final manuscript.

\section{AVAILABILITY OF DATA AND MATERIALS}

All data generated or analysed during this study are included in this published research article. 
The interviewees were informed about the objectives of the research study and eventually publication of the information gathered, and they were assured that the informants 'identities would remain undisclosed.

\section{Ethics approval and content to participate}

A verbal agreement was obtained from the informants prior to data collection and informants' consent agreement was taken from the informants.

\section{CONFLICT OF INTEREST}

Authors have no conflict of interest.

\section{FUNDING}

Not applicable.

\section{References}

Baharum SN, Beng EK and Mokhtar MAA (2010) Marine Microorganisms: Potential Application and Challenges. J of Biological Sciences 10 (6): 555-64. https://doi.org/10.3923/jbs.2010.555.564

Centre, International, and F O R Environment (2017) Green Files" 23 (December)

Chandra, Kailash, Daizy Bharti, Santosh Kumar, and C Raghunathan. n.d. Ramsar Wetlands of India Faunal Diversity In

Chandra, Kailash, Gopi Kc, Subramanian KA and Kandasamy Valarmathi (2018) Current Status of Freshwater Biodiversity of India: An Over View Faunal Diversity of India, no. May: 1-25

Chatterjee SA, Saikia, Pijush Dutta, Dipankar Ghosh, Govinda Pangging, and Anil K, Goswami (2006) Biodiversity Significance of North East India India, Delhi. 1-71

Convention, Ramsar (1990) Wetlands, Biodiversity and the Ramsar Convention Ramsar Convention CEPA Programme

Cowardin, Lewis M, Virginia Carter, Francis C. Golet and Edward T. Laroe (2005) Classification of Wetlands and Deepwater Habitats of the United States. Water Encyclopedia, no. December 1979. https://doi.org/10.1002/047147844x.sw2162.

ENVIS (2015) Centre, Directorate of Environment, Government of Manipur

Ghermandi, Andrea, Jeroen CJM, van den Bergh, Luke M. Brander, Henri LF. de Groot, and Paulo ALD Nunes (2011) The Economic Value of Wetland Conservation and Creation: A Meta-Analysis. SSRN Electronic Journal, no. I. https:// doi.org/10.2139/ssrn.1273002 
Jain, Alka and Singh HB (2014) Aquatic / Semi-Aquatic Plants Used in Herbal Remedies in the Wetlands of Manipur, Northeastern India, no. April 2007

Jain, Alka, Manju Sundriyal, Uttarakhand Science Education, Rumi Kotoky, and Singh HB (2011) Dietary Use and Conservation Concern of Edible Wetland Plants at Indo-Burma Hotspot: A Case Study from Northeast India, no. June 2014. https://doi.org/10.1186/1746-4269-7-29.

Jain A (2007) Edible aquatic biodiversity from the wetland of Manipur, Final technical report submitted to CSIR. New Delhi

Jain SK (1968) Medicinal Plants. National Book Trust India, New Delhi, 154

Kumar, Sunil and Rajesh Dhankhar (2015) Assessment of Floristic and Avian Faunal Diversity of Bhindawas Wetland, Jhajjar (Haryana), India. Plant Archives, 15 (2): 733-40

Ministry of Environment and Forests, Government of India (2010) NATIONAL WETLAND ATLAS:

Karnataka, 222

Moirangleima K (2007) Sustainable Management of Wetlands in the Central Valley of Manipur, 244

Rangana SC (1979) Manual of Analysis of Fruits and Vegetable Products, Tata McGraw Hill, New Delhi, India

SACONH (2004) Inland Wetlands of India-Conservation Atlas, Salim Ali Centre for Ornithology and Natural History, Coimbatore, India

Singh AL and Khundrakpam M (2009) Shrinking Water Area in the Wetlands of the Central Valley of Manipur, 1-5

Singh HB, Singh RS and Sandhu JS (2003) Herbal Medicine of Manipur- A Colour Encyclopaedia, (Daya Publishing House, New Delhi)

Singh RP (1982) Geography of Manipur, National Book Trust, New Delhi

Sinha SC (1987) Ethnobotany of Manipur Medicinal Plants. Front. Bot. 1,123-156

Sinha SC (1996) Medicinal Plants of Manipur, (Sinha and MASS, Imphal, India)

Sundriyal M, Sundriyal RC (2004) Wild edible plants of the Sikkim Himalaya: Marketing, value addition and implications for management, Eco Bot. 58(2):300-315

Venkataraman, Krishnamoorthy, and Chandrakasan Sivaperuman (2018) Biodiversity Hotspots in India. Indian Hotspots: Vertebrate Faunal Diversity, Conservation and Management Volume 1, 1-27. https://doi.org/10.1007/978-981-10-6605-4_1 
Vijayan, Nidhi, Sagadevan E, Arumugam P, Jaffar HA and Jayaprakashvel M (2012) Screening of Marine Bacteria for Multiple Biotechnological Applications 1 (November): 348-54

WHO (2003) WHO Monographs on Selected Medicinal Plants 1, Geneva

\section{Tables}

Table 1: Traditional usage of common aquatic plants found in central valley of Manipur 


\begin{tabular}{|c|c|c|c|c|}
\hline Scientific name & Family & $\begin{array}{l}\text { Local } \\
\text { name }\end{array}$ & Traditional usage & Availability \\
\hline Acorus calamus L. & Araceae & Ok-hidak & $\begin{array}{l}\text { The rhizomes have a characteristic } \\
\text { aromatic smell that is specially used by } \\
\text { children during cough and fever by } \\
\text { hanging it from their necks. } 5-10 \mathrm{ml} \text { of } \\
\text { the extracted juice of rhizome mixed } \\
\text { with honey is prescribed twice a day } \\
\text { before food during severe cough, piles, } \\
\text { chest congestion, stomach ulcer and } \\
\text { epilepsy, glandular and abdominal } \\
\text { tumors. Sometimes rhizome is often } \\
\text { chewed to get relief from asthma and } \\
\text { insect bite. A steam-heated packet } \\
\text { containing rhizome, leaves of Cannabis } \\
\text { sativa with Datura stramonium is } \\
\text { applied as foment during body pain. } \\
\text { The oil extracted from the rhizome is } \\
\text { applied externally to the person having } \\
\text { piles. }\end{array}$ & $\begin{array}{l}\text { Not so } \\
\text { common }\end{array}$ \\
\hline $\begin{array}{l}\text { Alocasia } \\
\text { cuculata (L.) } \\
\text { Schott. }\end{array}$ & Araceae & Singjupan & $\begin{array}{l}\text { Ethnomedicinal uses: Petiole juice is } \\
\text { applied externally on fresh-cut and } \\
\text { injuries for early healing. Corm cooked } \\
\text { with fermented soybean is eaten or } \\
\text { prepared as a traditional salad called } \\
\text { 'Singju' (a mixture with fermented fish, } \\
\text { chili, and other plants). }\end{array}$ & $\begin{array}{l}\text { Not so } \\
\text { common }\end{array}$ \\
\hline $\begin{array}{l}\text { Amaranthus } \\
\text { spinosus L. }\end{array}$ & Amaranthaceae & $\begin{array}{l}\text { Chengkruk } \\
\text { tingkhang } \\
\text { panbi }\end{array}$ & $\begin{array}{l}\text { The crushed root is applied externally } \\
\text { as a poultice in early symptoms of } \\
\text { leprosy, bruises. Steam heated packed } \\
\text { containing the plant and Mimosa } \\
\text { pudica is applied as foment to the }\end{array}$ & Very common \\
\hline
\end{tabular}




\begin{tabular}{|c|c|c|c|c|}
\hline & & & $\begin{array}{l}\text { person having rheumatic pain. Boiled } \\
\text { extract of the plant is advised to the } \\
\text { person having constipation, extract } \\
\text { mixed with sugar is given to the person } \\
\text { having leucorrhea, jaundice, } \\
\text { hemorrhoid. Pounded shoot mixed with } \\
\text { egg is applied in case of skin burns } \\
\text { and mixed with lime is prescribed in } \\
\text { case of skin sores. Young shoots and } \\
\text { tender leaves are incorporate in the } \\
\text { preparation of traditional dishes like } \\
\text { kangsoi. }\end{array}$ & \\
\hline Cyperus haspan L. & Cyperaceae & Kauthum & $\begin{array}{l}\text { Boiled extract of the tuber consumes } \\
\text { to relieve thirst to a diabetic patient, } \\
\text { extracted rhizome with honey is used } \\
\text { in fever and bronchitis. The tuber } \\
\text { incorporates in the preparation of } \\
\text { famous local dish 'Eronba' and } \\
\text { Bora (Pakora). }\end{array}$ & $\begin{array}{l}\text { Not so } \\
\text { common }\end{array}$ \\
\hline $\begin{array}{l}\text { Enhydra } \\
\text { fluctuans Lour. }\end{array}$ & Asteraceae & $\begin{array}{l}\text { Komprek } \\
\text { tujombi }\end{array}$ & $\begin{array}{l}\text { The crushed extract of the plant mixed } \\
\text { with mustard oil gives to the person } \\
\text { suffering from scabies and other skin } \\
\text { diseases; } 5-10 \mathrm{ml} \text { of a boiled extract of } \\
\text { the plant is prescribed against } \\
\text { diabetes every day. The boiled } \\
\text { decoction of the plant prescribes to the } \\
\text { person suffering from urinary troubles, } \\
\text { diarrhea, dysentery, and other bowel } \\
\text { complaints. The fresh plant is given as } \\
\text { an antidote to food poisoning by the } \\
\text { local medicine-man. Plant cooked with } \\
\text { little water consumes twice a day to }\end{array}$ & $\begin{array}{l}\text { Not so } \\
\text { common }\end{array}$ \\
\hline
\end{tabular}




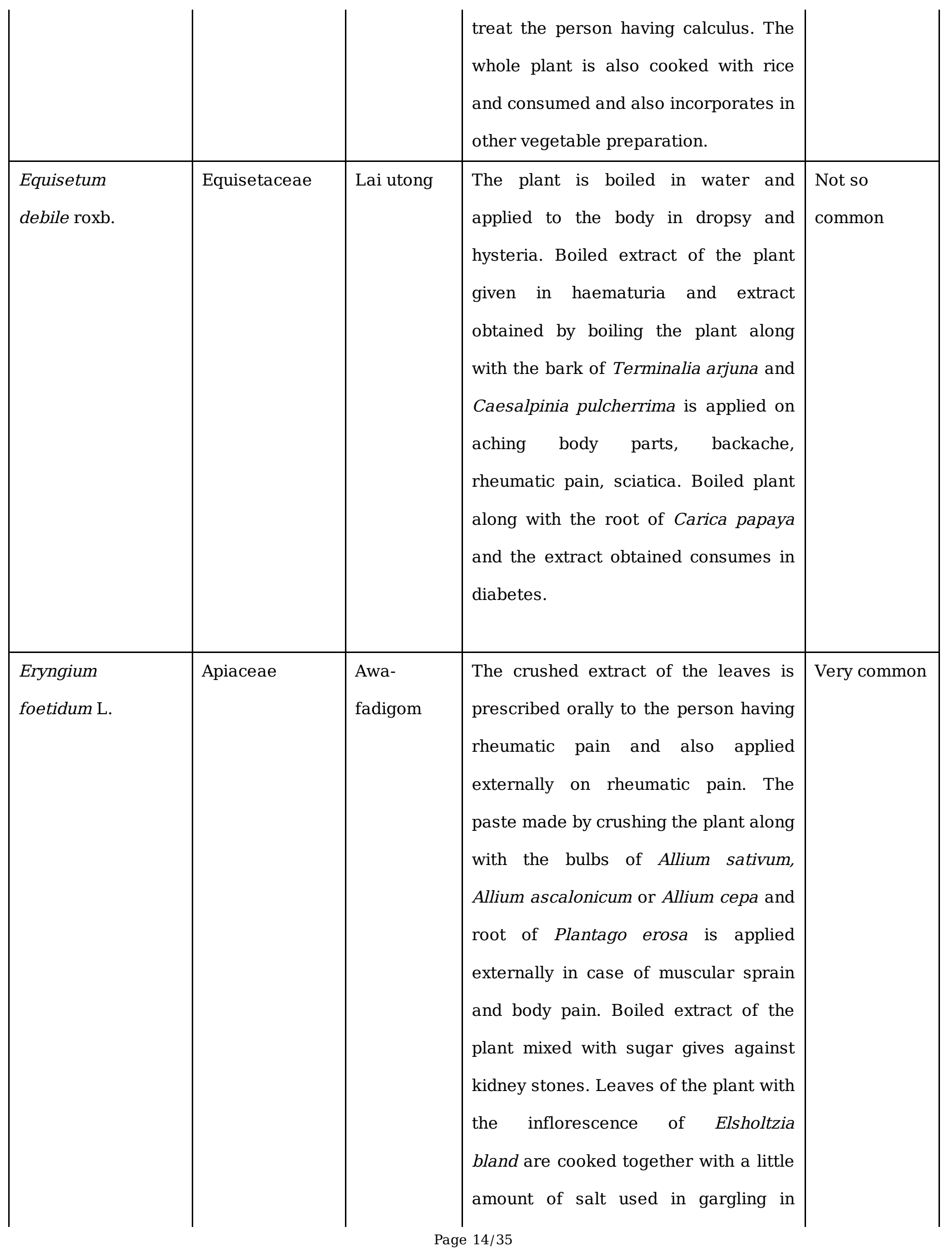




\begin{tabular}{|c|c|c|c|c|}
\hline & & & $\begin{array}{l}\text { tonsillitis. Pills were made by crushing } \\
\text { the leaves along with the bulbs of } \\
\text { Allium sativum and locally fermented } \\
\text { fish ngari consumed to lower blood } \\
\text { pressure. The paste was made by } \\
\text { crushing the plant along with the } \\
\text { rhizome of Zingiber officinale, bulbs of } \\
\text { Allium sativum, seeds of Brassica } \\
\text { juncea, and local fermented fish ngari } \\
\text { also used as massage in case of } \\
\text { paralysis. } 4-5 \mathrm{~g} \text { of leaves of the plant is } \\
\text { consumed with vegetables every day in } \\
\text { epilepsy and paralysis. }\end{array}$ & \\
\hline $\begin{array}{l}\text { Euryale } \\
\text { ferox Salisb. }\end{array}$ & Nymphaeaceae & Thangjing & $\begin{array}{l}\text { The rhizome of the plant prescribes for } \\
\text { the treatment of dropsy, jaundice, and } \\
\text { gonorrhea. The rhizome boiling with a } \\
\text { piece of alum prescribes for the } \\
\text { treatment of scabies. The petioles and } \\
\text { seeds are cooked and used as a } \\
\text { vegetable. Crushed juice of the petiole } \\
\text { is applied externally in case of burns } \\
\text { and inflammation and is also } \\
\text { consumed as raw in abdominal } \\
\text { inflammations. Seeds are tonic and } \\
\text { astringent. Fresh fruit prescribed for } \\
\text { diabetes patients; leaf petiole paste } \\
\text { applied to burns and boils. Seed flour } \\
\text { consumes as a substitute for } \\
\text { arrowroot and easily digestible. It is } \\
\text { useful in burns, leucorrhoea, and } \\
\text { postpartum weakness. }\end{array}$ & Very common \\
\hline Hedychium & Zingiberaceae, & Loklei & Rhizome paste is an appetizer and & Not so \\
\hline
\end{tabular}




\begin{tabular}{|c|c|c|c|c|}
\hline coronarium Koenig. & & & $\begin{array}{l}\text { used in cough and fever. Rhizome } \\
\text { crushed or extract given to the person } \\
\text { having bronchitis and the decoction of } \\
\text { rhizomes used for gargling in tonsillitis } \\
\text { or used as a mouth wash to avoid bad } \\
\text { breath. The rhizome paste applies to } \\
\text { bruises and sprains. }\end{array}$ & common \\
\hline $\begin{array}{l}\text { Hedyotis } \\
\text { auricularia Roxb. }\end{array}$ & Rubiaceae & $\begin{array}{l}\text { Langban- } \\
\text { koukha }\end{array}$ & $\begin{array}{l}\text { The extracts of the leaf juice prescribe } \\
\text { to the person having jaundice. The } \\
\text { plant wrapped with banana leaf is } \\
\text { warming up on the burning charcoal is } \\
\text { applied as bandage against muscular } \\
\text { sprain. }\end{array}$ & Very common \\
\hline $\begin{array}{l}\text { Houttuynia } \\
\text { cordata Thunb. }\end{array}$ & Saururaceae & Toningkhok & $\begin{array}{l}\text { The crushed leaves extract of about } 5 \text { - } \\
10 \mathrm{ml} \text { is prescribed to the person } \\
\text { having diarrhea and dysentery. The } \\
\text { crushed rhizome use in case of } \\
\text { stomach ulcers and skin diseases. } \\
\text { Boiled extract of the rhizome } \\
\text { consumes orally in case of muscular } \\
\text { pain due to overstrains. } 4-5 \text { fresh } \\
\text { leaves give to the person suffering } \\
\text { from measles, dysentery, and } \\
\text { gonorrhea, hemorrhoids, eye, and skin } \\
\text { troubles. } 4 \text {-5 leaves crushed together } \\
\text { are applied externally as a poultice on } \\
\text { boils and skin sores. Leaves decoction } \\
\text { obtained from the boiling of about } 5 \text {-10 } \\
\text { ml is advised to consume for the } \\
\text { treatment of many ailments including } \\
\text { cancer, coughs, dysentery, enteritis, } \\
\text { and fever. It is also eaten raw to }\end{array}$ & Very common \\
\hline
\end{tabular}




\begin{tabular}{|c|c|c|c|c|}
\hline & & & $\begin{array}{l}\text { strengthen the immune system. } \\
\text { Externally, the crushed leaves apply } \\
\text { for the treatment of snake bites and } \\
\text { skin disorders. The plant consumes as } \\
\text { a spice for curry and salad. }\end{array}$ & \\
\hline $\begin{array}{l}\text { Hydrocotyle } \\
\text { sibthorpioides Lam. }\end{array}$ & Apiaceae & $\begin{array}{l}\text { Lei/Lai- } \\
\text { peruk }\end{array}$ & $\begin{array}{l}\text { Fresh leaf extract consumes in cough, } \\
\text { fever, and jaundice. The crushing plant } \\
\text { of about } 100 \mathrm{gm} \text { is soaked in } 1 \text { liter of } \\
\text { lukewarm water and kept for 1-2 } \\
\text { hours. The filtrate obtained is } \\
\text { consumed in a glass daily to treat } \\
\text { cough, fever, and jaundice. }\end{array}$ & Very common \\
\hline $\begin{array}{l}\text { Ipomea } \\
\text { aquatica Forsk. }\end{array}$ & Convolvulaceae & Kolamni & $\begin{array}{l}\text { The plant is eaten raw to cure } \\
\text { cardiovascular diseases and paralysis. } \\
\text { The decoction of the plant obtained by } \\
\text { boiling with water is advised to } \\
\text { consume for proper blood circulation, } \\
\text { debility, and used as purgative. The } \\
\text { crushed extract of the plant juice } \\
\text { obtained from mixing with salt applies } \\
\text { in the case of ringworm. The smashed } \\
\text { plant is applied externally as a poultice } \\
\text { on swelling joints, insect bites. The } \\
\text { extracted juice of the leaves massages } \\
\text { on the face in acne, pimples. The } \\
\text { extract of tender shoot obtained by } \\
\text { boiling prescribes to ease the thirst for } \\
\text { diabetic patients. The plant } \\
\text { incorporates in the preparation of } \\
\text { various traditional dishes viz. salad } \\
\text { (Sinju), eronba, kanghou, etc. Leaves } \\
\text { of the plant apply to reduce pain when }\end{array}$ & Common \\
\hline
\end{tabular}




\begin{tabular}{|c|c|c|c|c|}
\hline & & & $\begin{array}{l}\text { rubbed on the spot of insect bites. The } \\
\text { plant considers as a healthy food for } \\
\text { females having nervous and general } \\
\text { weakness. A decoction of fresh shoot } \\
\text { and leaves use as droplets against } \\
\text { otorrhoea and retinitis. Sometimes } \\
\text { boiled extract of the root mixed with } \\
\text { honey is given to the person suffering } \\
\text { from severe fever and malaria. The } \\
\text { tender shoot cooked with lata } \\
\text { fish (Chana Orientalis) consumes } \\
\text { having diarrhea and dysentery. The } \\
\text { extract obtained by crushing the plant } \\
\text { with Drymaria cordata is applied } \\
\text { externally all over the body to } \\
\text { decrease the high body temperature of } \\
\text { the child. }\end{array}$ & \\
\hline Jussiaea repens L. & Onagraceae & Ising kundo & $\begin{array}{l}\text { The boiled extract of the plant } \\
\text { prescribes to the person having } \\
\text { diabetes and menstrual disorder. } \\
\text { Crushed extract of the fresh plant is } \\
\text { applied externally on body pain and } \\
\text { inflammation. The juice obtained by } \\
\text { the crushing of the plant prescribes to } \\
\text { the person having urinary trouble. The } \\
\text { plant incorporates in the preparation } \\
\text { of traditional dish salad (singju). } \\
\text { Crushed leaves apply to ringworms } \\
\text { and other parasitic skin infections. The } \\
\text { paste obtained from Fresh leaves } \\
\text { applies externally in case of boils and } \\
\text { burns as coolant. The cooked shoot }\end{array}$ & Very common \\
\hline
\end{tabular}




\begin{tabular}{|c|c|c|c|c|}
\hline & & & $\begin{array}{l}\text { consumes in an empty stomach against } \\
\text { strangury. The tender shoot cook with } \\
\text { lata fish (Chana Orientalis) prescribes } \\
\text { as an energizer in weakness. }\end{array}$ & \\
\hline $\begin{array}{l}\text { Leucas } \\
\text { aspera Spreng. }\end{array}$ & Lamiaceae & $\begin{array}{l}\text { Mayang } \\
\text { lembum }\end{array}$ & $\begin{array}{l}\text { The crushed extract of the plant } \\
\text { prescribes to the person having piles } \\
\text { and menstrual disorders. The crushed } \\
\text { extract of the plant is also applied } \\
\text { externally for the treatment of scabies, } \\
\text { body pain, and the same consumes to } \\
\text { the person having diarrhea and } \\
\text { dysentery. The tender shoot of the } \\
\text { plant cooked with lata fish (Chana } \\
\text { Orientalis) is advised to treat } \\
\text { menstrual disorder; the paste of the } \\
\text { tender shoots is applied externally on } \\
\text { the forehead to relieve headache. The } \\
\text { boiled extract of the plant is given } \\
\text { orally for the healing of piles, } \\
\text { bronchitis, asthma, and body pain. The } \\
\text { leaves, flowers, and young stems use } \\
\text { to purify the blood. The leaves juice is } \\
\text { applied externally to the poisonous } \\
\text { insect bite. Flower consumes as raw to } \\
\text { reduce cough and cold. Leaves juice } \\
\text { prescribes to the person having skin } \\
\text { eruptions and painful swellings. }\end{array}$ & $\begin{array}{l}\text { Not so } \\
\text { common }\end{array}$ \\
\hline Marsilea minuta L. & Marsileaceae & $\begin{array}{l}\text { Ishing- } \\
\text { yensang }\end{array}$ & $\begin{array}{l}\text { Fresh plant decoction consumes twice } \\
\text { a day for 10-12 days against strangury. } \\
\text { The paste obtained from the root is } \\
\text { applied externally to the person having } \\
\text { eczema. The aerial parts of the plants }\end{array}$ & Common \\
\hline
\end{tabular}




\begin{tabular}{|c|c|c|c|c|}
\hline & & & $\begin{array}{l}\text { use in the preparation of traditional } \\
\text { dishes ooti and kangsoi. }\end{array}$ & \\
\hline $\begin{array}{l}\text { Nasturtium } \\
\text { indicum L. }\end{array}$ & Brassicaceae, & $\begin{array}{l}\text { Uchi- } \\
\text { hangam }\end{array}$ & $\begin{array}{l}\text { The whole plant cooked is eaten } \\
\text { regularly for the treatment of diabetes } \\
\text { and dysentery. Fresh shoot decoction } \\
\text { advised in the empty stomach against } \\
\text { strangury once a day for a week. }\end{array}$ & Very common \\
\hline $\begin{array}{l}\text { Nelumbo } \\
\text { nucifera Gaertner. }\end{array}$ & Nelumbonaceae & Thambal & $\begin{array}{l}\text { Plant leaves cooked with prawns } \\
\text { (Palaomon malcolmsonil) are } \\
\text { consumed by the person having } \\
\text { diabetes twice or thrice daily. One } \\
\text { spoonful of rhizome paste mixed with } \\
\text { little honey is advised to the person } \\
\text { having diabetes daily for about two } \\
\text { weeks. The extract obtained by boiling } \\
\text { the tender shoot along with } \\
\text { Phyllanthus fraturnus prescribes for } \\
\text { the treatment of diabetes patients. The } \\
\text { decoction obtained by boiling the } \\
\text { flower consumes for blood purification. } \\
\text { Roots, flowers, and seeds of the plant } \\
\text { are used as a remedy for the } \\
\text { treatment of various ailments viz. } \\
\text { diarrhea, cholera, liver, cardiac } \\
\text { complaints, piles, bleeding, and } \\
\text { leprosy. The seeds can be eaten raw } \\
\text { or in the form of chutney. Sometimes } \\
\text { the seed kernel is consumed as fresh } \\
\text { to improve eye vision. Rhizomes, roots, } \\
\text { seeds, and young leaves of the plant } \\
\text { consume as vegetables by } \\
\text { incorporating various traditional }\end{array}$ & Common \\
\hline
\end{tabular}




\begin{tabular}{|c|c|c|c|c|}
\hline & & & $\begin{array}{l}\text { dishes. Rolled tender leaves are } \\
\text { consumed raw or as a salad (sinju) for } \\
\text { the treatment of strangury. The petiole } \\
\text { is consumed regularly for the } \\
\text { treatment of stomach ulcers. The } \\
\text { smashed root is applied externally on } \\
\text { ringworms and other skin infections. } \\
\text { The pounded leaves apply externally } \\
\text { on the forehead to reduce headaches. } \\
\text { Leaf petiole is eaten raw for the } \\
\text { treatment of stomach problems and } \\
\text { better urination. Leaves and seed } \\
\text { cores extract believe as good for the } \\
\text { treatment of the person having } \\
\text { insomnia, and hematemesis. }\end{array}$ & \\
\hline $\begin{array}{l}\text { Neptunia } \\
\text { oleraceae Lour. }\end{array}$ & Mimosaceae & $\begin{array}{l}\text { Eshing } \\
\text { ikaithabi }\end{array}$ & $\begin{array}{l}\text { The extract of the plant boiled with a } \\
\text { little bit of common salt prescribes to } \\
\text { the person having stomach ulcers and } \\
\text { other stomach complaints. The leaf of } \\
\text { the plant consumes raw to treat } \\
\text { dysentery and intestinal infection. } \\
\text { Alternatively, a decoction made by } \\
\text { crushing the leaves of the plant with } \\
\text { little water prescribes to the person } \\
\text { having intestinal infection twice a day } \\
\text { until cured. And the same decoction } \\
\text { prepared is also given to the person } \\
\text { having parasitic worm infections twice } \\
\text { a day for three days. The crushed } \\
\text { extract of the plant applies as an ear } \\
\text { dropped in otitis and applied to } \\
\text { glandular swellings on the neck. The }\end{array}$ & Common \\
\hline
\end{tabular}




\begin{tabular}{|c|c|c|c|c|}
\hline & & & $\begin{array}{l}\text { decoction obtained by boiling the stem } \\
\text { along with sugar candy, Centella } \\
\text { Asiatica, inflorescence of Elsholttzia } \\
\text { blanda prescribes for the treatment of } \\
\text { worm infection in children. A paste } \\
\text { made by crushing the leaf of the plant } \\
\text { with Mimosa pudica is applied } \\
\text { externally overboils; the extract } \\
\text { obtained applies to other skin } \\
\text { diseases. The young stem and leaves } \\
\text { consume as vegetables in the } \\
\text { preparation of local dishes viz. salad } \\
\text { ( sinju), chagem-pomba, kanghou } \\
\text { eronba, etc. Juice of the stem applies } \\
\text { to relieve earache. The pounded } \\
\text { leaves and stem of the plant apply over } \\
\text { the nose to treat syphilis ulcers or } \\
\text { necrosis of the nose. }\end{array}$ & \\
\hline $\begin{array}{l}\text { Nymphaea } \\
\text { stellata Willd. }\end{array}$ & Nymphaeaceae & Thariktha & $\begin{array}{l}\text { The paste obtained from fresh petiole } \\
\text { of the plant mixed with seed powder } \\
\text { of Cuminum cyminum, common salt, } \\
\text { milk, butter, and honey prescribes to } \\
\text { the person having dysmenorrhoea } \\
\text { twice a day for } 2-3 \text { days. }\end{array}$ & $\begin{array}{l}\text { Not so } \\
\text { common }\end{array}$ \\
\hline $\begin{array}{l}\text { Nymphoides } \\
\text { indicum O. Kuntze. }\end{array}$ & Gentianaceae & $\begin{array}{l}\text { Tharo- } \\
\text { macha }\end{array}$ & $\begin{array}{l}\text { The paste of the plant applies } \\
\text { externally as a bandage in cut and } \\
\text { injury. Dried rhizome paste along with } \\
\text { little honey consume in diuresis. }\end{array}$ & $\begin{array}{l}\text { Not so } \\
\text { common }\end{array}$ \\
\hline $\begin{array}{l}\text { Oenanthe } \\
\text { javanica DC. }\end{array}$ & Umbelliferae & Komprek & $\begin{array}{l}\text { Leaves consume as appetizers and } \\
\text { digestive. } 1 / 3 \text { rd of a glass of whole } \\
\text { plant extract is given to the person to } \\
\text { lower high blood pressure and }\end{array}$ & $\begin{array}{l}\text { Not so } \\
\text { common }\end{array}$ \\
\hline
\end{tabular}




\begin{tabular}{|c|c|c|c|c|}
\hline & & & $\begin{array}{l}\text { diabetes. Half a glass of fresh leaves } \\
\text { juice prescribes to the person in case } \\
\text { of liver diseases, abdominal pain. } 5-10 \\
\text { ml fresh shoot decoction or shoot } \\
\text { cooked with rice consume in dieresis. } \\
5-10 \text { ml filtrate use as droplets against } \\
\text { otorrhoea. } 4-5 \text { leaves take as a salad } \\
\text { in dyspepsia. It is consumed as a } \\
\text { vegetable in salads, fresh or boiled } \\
\text { chutney, locally as Singju and Eromba } \\
\text { since the olden days. All the plant } \\
\text { parts are aromatic and have unique for } \\
\text { their specific aromatic taste and flavor } \\
\text { in local food habits. It is available all } \\
\text { year round and a good source of } \\
\text { vegetables for most of the local } \\
\text { people. }\end{array}$ & \\
\hline $\begin{array}{l}\text { Plantago } \\
\text { erosa Wall. }\end{array}$ & Plantaginaceae & Yempat & $\begin{array}{l}\text { The boiled extract of the leaves and } \\
\text { root mixed with sugar is prescribed to } \\
\text { the person for better flow of urine, } \\
\text { elimination of stones in the kidney and } \\
\text { gall bladder, colic, cough, inflammation } \\
\text { of the kidney and urinary bladder, } \\
\text { fever, and constipation. Leaves and } \\
\text { roots of the plant prescribe to the } \\
\text { person for the treatment of chronic } \\
\text { fever. The paste obtained from the } \\
\text { crushing of the plant along with the } \\
\text { bulbs of Allium sativum, Allium } \\
\text { ascalonicum, Eryngium foetidum use } \\
\text { as massage for the treatment of body } \\
\text { pain, muscular sprain, and also in }\end{array}$ & $\begin{array}{l}\text { Not so } \\
\text { common }\end{array}$ \\
\hline
\end{tabular}




\begin{tabular}{|c|c|c|c|c|}
\hline & & & $\begin{array}{l}\text { rheumatism. Extract of the leaves } \\
\text { mixed with honey advised orally to the } \\
\text { person having high body temperature, } \\
\text { stomach ulcers, and other stomach } \\
\text { complaints. The seed prescribes to the } \\
\text { person having diarrhea, dysentery, } \\
\text { constipation, and genito-urinary tract } \\
\text { complaints. Tender leaves of the } \\
\text { plants eat vegetables. }\end{array}$ & \\
\hline $\begin{array}{l}\text { Polygonum } \\
\text { barbatum L. }\end{array}$ & Polygonaceae & Yelang & $\begin{array}{l}\text { The leaves of the plant after slightly } \\
\text { warming on charcoal fire applies in } \\
\text { local healing, the decoction of leaves } \\
\text { and shoots of about half glass } \\
\text { consumes as a stimulating wash for } \\
\text { ulcers. Leave paste of about } 5 g \text { is used } \\
\text { externally for the treatment of } \\
\text { cutaneous infection. Boiled extract of } \\
\text { the leaves of about one glass } \\
\text { prescribes to the person having } \\
\text { diarrhea, dysentery, colic, and stomach } \\
\text { complaints every day. The vegetable } \\
\text { believes to be clearing up the } \\
\text { intestinal tract by its regular use. The } \\
\text { roots of the plant consume as } \\
\text { astringent and cooling. Seed powder of } \\
\text { the plant soaked in water is consumed } \\
\text { regularly against strangury. Tender } \\
\text { leaves and young shoots are commonly } \\
\text { taken as vegetables in curry form viz. } \\
\text { kangsoi, eromba, singju, etc. }\end{array}$ & $\begin{array}{l}\text { Not so } \\
\text { common }\end{array}$ \\
\hline $\begin{array}{l}\text { Polygonum } \\
\text { perfoliatum L. }\end{array}$ & Polygonaceae & Lilhar & $\begin{array}{l}\text { The warmed plant wrapped in banana } \\
\text { leaf is applied externally on wounds \& }\end{array}$ & Common \\
\hline
\end{tabular}




\begin{tabular}{|c|c|c|c|c|}
\hline & & & $\begin{array}{l}\text { injuries and also for the healing of } \\
\text { muscular sprain. The paste obtained } \\
\text { from seed powder was used externally } \\
\text { as an antidote to snakebite. }\end{array}$ & \\
\hline $\begin{array}{l}\text { Polygonum } \\
\text { posumba Ham. }\end{array}$ & Polygonaceae & Phakpai & $\begin{array}{l}\text { The leave of the plant cooked with a } \\
\text { local fish Ngakha meingangbi (Puntius } \\
\text { phutunio) consumes for the treatment } \\
\text { of diarrhea and other stomach } \\
\text { complaints. The crushed extract of the } \\
\text { plant is applied externally to treat skin } \\
\text { allergies. The juice obtained by } \\
\text { crushing the plant along with Eryngium } \\
\text { foetidum and Leucas Aspera } \\
\text { prescribes orally as well as applied } \\
\text { externally on muscle weakness and } \\
\text { paralysis. Young shoots of the plant } \\
\text { are advised for the management of } \\
\text { hypertension. Crushed leaves of plant } \\
\text { juice dissolved in a glass of warm } \\
\text { water prescribe to the person having } \\
\text { gastric problems once or twice a day. } \\
\text { The leaves consume as vegetables in } \\
\text { the preparation of local dish eromba } \\
\text { and salad (singju). }\end{array}$ & $\begin{array}{l}\text { Not so } \\
\text { common }\end{array}$ \\
\hline $\begin{array}{l}\text { Ranunculus } \\
\text { scleratus L. }\end{array}$ & Ranunculaceae & $\begin{array}{l}\text { Kakyel- } \\
\text { khujil }\end{array}$ & $\begin{array}{l}\text { Plant wrapped in a banana leaf that is } \\
\text { burnt slightly in the burning charcoal is } \\
\text { applied externally to the person having } \\
\text { gout. }\end{array}$ & Common \\
\hline $\begin{array}{l}\text { Sagittaria } \\
\text { sagittifolia L. }\end{array}$ & Alismataceae & Koukha & $\begin{array}{l}\text { Boiled extract of the rootstock is } \\
\text { applied externally for the treatment of } \\
\text { scabies, itches, and other skin } \\
\text { diseases. The powdered leaves use to }\end{array}$ & $\begin{array}{l}\text { Not so } \\
\text { common }\end{array}$ \\
\hline
\end{tabular}




\begin{tabular}{|c|c|c|c|c|}
\hline & & & $\begin{array}{l}\text { reduce itchiness. The powdered leaves } \\
\text { mixed with honey prescribes to the } \\
\text { person having sore throat and } \\
\text { inflammation of the breast. Vegetative } \\
\text { parts of the plant boiled with water } \\
\text { consume to control hypertension. }\end{array}$ & \\
\hline Trapa natans L. & Trapaceae & $\begin{array}{l}\text { Heikak } \\
\text { yetli }\end{array}$ & $\begin{array}{l}\text { Fruits cooked are eaten or as raw; } \\
\text { petiole consumes as vegetables in the } \\
\text { preparation of traditional dishes } \\
\text { eronba and singju. The plant consumes } \\
\text { to improve blood circulation and } \\
\text { leucorrhoea. Fresh tender kernels are } \\
\text { sweet, delicious, nutritious and a good } \\
\text { source of minerals and carbohydrates. } \\
\text { The fruits are astringent and used as } \\
\text { cooling; consume for the treatment of } \\
\text { constipation and also used as } \\
\text { appetizer and tonic. The fruit } \\
\text { prescribes to relieve thirst, urinary } \\
\text { disorders, and general weakness. }\end{array}$ & Common \\
\hline $\begin{array}{l}\text { Zizania } \\
\text { latifolia turez. }\end{array}$ & Poaceae & $\begin{array}{l}\text { Eshing } \\
\text { kambong }\end{array}$ & $\begin{array}{l}\text { Culms, rhizome, and grains of the } \\
\text { plant prescribe to the person having } \\
\text { anemia and fever, heart, kidney, and } \\
\text { liver troubles, and the paste obtained } \\
\text { is applied externally to burns and } \\
\text { injuries for early healing. Infected } \\
\text { culms forming galls filled up with } \\
\text { innumerable spores like cocoa powder } \\
\text { are eaten raw as digestive and } \\
\text { incorporate in the preparation of } \\
\text { vegetables. Infected fruit prescribes to }\end{array}$ & Common \\
\hline
\end{tabular}


the person having protein deficiency as

it is rich in protein.

Table 2: Wetlands plants used as vegetables or spices/condiments in traditional dishes: 


\begin{tabular}{|c|c|}
\hline $\begin{array}{l}\text { Name of } \\
\text { the local } \\
\text { dish }\end{array}$ & Preparation \\
\hline Ironba: & $\begin{array}{l}\text { It is a special dish prepared from several vegetables viz., Wendlanda (inflorescence), Sagittaria } \\
\text { (tuber), Solanum tuberosum, Musa paradasiaca, Amorphophalus sp., Abelmoscus esculentus, } \\
\text { etc. boiled together. The fermented fish mash with red chili with an appropriate amount of salt } \\
\text { mixed with all other cooked vegetables. The variation of the dish can also be made by adding } \\
\text { Ipomea aquatic, Oenanthe javanica, Euryale Ferox, Trapa natans, Sagittaria sagittifolia, } \\
\text { Polygonum barbatum, etc. The finished dish so prepared is garnished with finely chopped } \\
\text { Houttuinia cordata (roots, leaves), onion stalks, Elsholtzia blanda (inflorescence), Allium } \\
\text { odorum, etc. as condiments to give a characteristic aroma. }\end{array}$ \\
\hline Ametpa: & $\begin{array}{l}\text { It is spicy chutney prepared from boiled or steamed or fried chili mixed with fermented fish. } \\
\text { Consume with green leaves of Pisum sativum, Brassica campestris, Brassica oleracea, } \\
\text { Houttuinia cordata, Polygonum posumba, Polygonum barbatum, Euryale Ferox, Ipomea aquatic, } \\
\text { Oenanthe javanica, Neptunia oleraceae, etc. }\end{array}$ \\
\hline Singju: & $\begin{array}{l}\text { A traditional Meitei salad prepared from finely chopped raw vegetables like cabbage, onions, } \\
\text { lotus stems, tree beans, coriander, Alocasia cuculata, Ipomea aquatic, Oenanthe javanica, etc. } \\
\text { mixed with red pepper, sesame seeds, roasted gram flour, salt, boiled seeds of beans or pea, } \\
\text { fermented fish. The variations of dishes can prepare from raw papaya, cabbage, banana flower, } \\
\text { Nelumbo nucifera garnished with Allium odorum, Houttuinia cordata, etc. }\end{array}$ \\
\hline $\begin{array}{l}\text { Chagem- } \\
\text { pomba: }\end{array}$ & $\begin{array}{l}\text { A traditional dish item cook in a grand feast. Prepare using a combination of various kinds of } \\
\text { tender leaves (Neptunia oleraceae, Brassica juncea, Vicia faba, Parkia speciosa, Anethum } \\
\text { graveolens, Allium odorum, etc.) with ground rice, (chagem), red pepper, dried and fermented } \\
\text { fish, fermented soybean, and then cook together. }\end{array}$ \\
\hline Kangsu: & $\begin{array}{l}\text { It is a traditional dish similar to singju. It is a side dish prepared from boiled vegetables, } \\
\text { fermented fish mashed up together along with salt, red pepper powder. }\end{array}$ \\
\hline Ooti: & $\begin{array}{l}\text { It is a classic traditional dish considers as a compulsory main dish in a grand feast. Prepare } \\
\text { from pea, several green leafy vegetables, with or without grounded rice. It is the only dish } \\
\text { prepared added with sodium bicarbonate. Amaranthus spinosus, Colocasia esculenta, } \\
\text { Clerodendrum Indicum, Brassica oleracea, Marsilea minuta, etc. used as green leafy vegetables } \\
\text { for the preparation but varieties can make using bamboo shoots, black gram dhal, Bengal gram } \\
\text { dhal, etc. }\end{array}$ \\
\hline Champhut: & dish prepared by boiling several seasonal vegetables with or without \\
\hline
\end{tabular}




\begin{tabular}{|c|c|}
\hline & \\
\hline Kanghou: & $\begin{array}{l}\text { Several finely sliced vegetables (like Zizania latifolia, Ipomea aquatic, Neptunia oleraceae, } \\
\text { Amaranthus spinosus, Allium odorum, etc.) are stir-fried together with pulses or potato or } \\
\text { prawn. }\end{array}$ \\
\hline Hentak: & $\begin{array}{l}\text { It is a side dish prepared from phabou ngari (dry fish). Phabou ngari pounded with petioles of } \\
\text { Alocasia macrorrhiza with the help of pestle and mortar and mixed until it forms a single } \\
\text { uniform texture and is then hand-rolled into balls. Used as a taste enhancer in the preparation } \\
\text { of kangsoi, Chamthong, ad advised to young mothers restricted from taking fermented fish. }\end{array}$ \\
\hline $\begin{array}{l}\text { Pakoura } \\
\text { thongba: }\end{array}$ & $\begin{array}{l}\text { A dish prepared by adding bora (pakora) is already cooked curry soup made up of dal (Cajanus } \\
\text { cajan or vegetable curry). There are many kinds of Bora viz. Koukha (Sagittaria } \\
\text { sagittifolia) bora, potato bora, onion bora, prawn bora, brinjal bora, cauliflower bora, thambou } \\
\text { (Nelumbo nucifera) bora, pumpkin bora, etc. }\end{array}$ \\
\hline Kangsoi & $\begin{array}{l}\text { It is a special traditional dish prepared by frying different seasonal vegetables (Polygonum } \\
\text { barbatum, Marsilea minuta, Oenanthe javanica, Amaranthus spinosus, potato, green pea, etc) } \\
\text { with coarsely chopped onions, Allium odorum, ginger, and garlic cloves, salt in a little bit of oil. } \\
\text { The dish is topped with fermented fish ngari and water. }\end{array}$ \\
\hline Chamthong & $\begin{array}{l}\text { It is a healthy vegetable stewed that consists of seasonal vegetables that are boiled together } \\
\text { with fermented fish/dried fish and flavored with sliced onions, garlic, salt, Allium odorum, and a } \\
\text { bit of ginger. It is somewhat similar to kangsoi but without oil. }\end{array}$ \\
\hline
\end{tabular}

Table 3: Mineral content in selected aquatic plant (values are \pm SD)

\begin{tabular}{|c|c|c|c|c|c|c|}
\hline Sl.No & Botanical name & $\begin{array}{c}\text { Parts of the plant } \\
\text { used }\end{array}$ & Iron (ppm) & $\begin{array}{c}\text { Magnesium } \\
(\mathrm{ppm})\end{array}$ & Ca (ppm) & Zinc (ppm) \\
\hline 1 & Zizania latifolia & Rhizome & $3.13 \pm 0.04$ & $0.62 \pm 0.01$ & $1.50 \pm 0.01$ & $1.61 \pm 0.01$ \\
\hline 2 & $\begin{array}{c}\text { Neptunia } \\
\text { oleraceae }\end{array}$ & Tender shoot & $8.07 \pm 0.005$ & $18.01 \pm 0.07$ & $51.45 \pm 0.79$ & $1.01 \pm 0.04$ \\
\hline 3 & Ipomea aquatica & Tender shoot & $8.44 \pm 0.27$ & $4.64 \pm 0.13$ & $9.45 \pm 0.29$ & $1.70 \pm 0.002$ \\
\hline 4 & Jussiaea repens & Tender shoot & $22.11 \pm 0.41$ & $7.10 \pm 0.02$ & $14.10 \pm 0.002$ & $1.17 \pm 0.20$ \\
\hline 5 & $\begin{array}{c}\text { Enhydra } \\
\text { fluctuans }\end{array}$ & Tender shoot & $12.78 \pm 0.002$ & $7.11 \pm 0.06$ & $16.11 \pm 0.19$ & $1.44 \pm 0.09$ \\
\hline 6 & Eleocharis dulcis & Rhizome & $11.18 \pm 0.04$ & $1.03 \pm 0.07$ & $2.01 \pm 0.16$ & $0.61 \pm 0.02$ \\
\hline 7 & $\begin{array}{c}\text { Sagittaria } \\
\text { sagittifolia }\end{array}$ & Tuber & $15.21 \pm 0.05$ & $0.98 \pm 0.001$ & $2.13 \pm 0.03$ & $1.47 \pm 0.04$ \\
\hline 8 & $\begin{array}{c}\text { Marsilea } \\
\text { quadrifolia }\end{array}$ & Whole plant & $16.44 \pm 0.10$ & $3.82 \pm 0.05$ & $7.70 \pm 0.19$ & $1.03 \pm 0.07$ \\
\hline 9 & Trapan natas & Tender shoot & $12.89 \pm 0.01$ & $21.20 \pm 0.018$ & $54.01 \pm 0.21$ & $0.80 \pm 0.003$ \\
\hline 10 & $\begin{array}{c}\text { Nelumbo } \\
\text { nucifera }\end{array}$ & Root & $5.21 \pm 0.29$ & $1.72 \pm 0.05$ & $3.85 \pm 0.008$ & $0.63 \pm 0.04$ \\
\hline
\end{tabular}


Table 4: Community matrix ranking for aquatic plant species for use, taste, availability and conservation status in Manipur, India. 


\begin{tabular}{|c|c|c|c|c|c|c|}
\hline Botanical names & Local name & $\begin{array}{l}* \text { Use } \\
\text { status }\end{array}$ & $\begin{array}{l}\text { Taste } \\
\text { preference* }\end{array}$ & $\begin{array}{l}\text { Availability } \\
\text { status* }\end{array}$ & $\begin{array}{l}\text { Conservation } \\
\text { status* }\end{array}$ & $\begin{array}{l}\text { Total } \\
\text { score }\end{array}$ \\
\hline Acorus calamus & Ok-hidak & 1 & 1 & 2 & 2 & 6 \\
\hline Alocasia cuculata & Singjupan & 4 & 4 & 2 & 4 & 14 \\
\hline $\begin{array}{l}\text { Amaranthus } \\
\text { spinosus }\end{array}$ & $\begin{array}{l}\text { Chengkruk } \\
\text { tingkhang panbi }\end{array}$ & 2 & 2 & 2 & 2 & 8 \\
\hline Cyperus haspan & Kauthum & 3 & 4 & 2 & 3 & 4 \\
\hline Enhydra fluctuans & Komprek tujombi & 3 & 3 & 2 & 3 & 11 \\
\hline Equisetum debile & Lai utong & 1 & 1 & 2 & 2 & 6 \\
\hline $\begin{array}{l}\text { Eryngium } \\
\text { foetidum }\end{array}$ & Awa-fadigom & 4 & 4 & 3 & 2 & 13 \\
\hline Euryale ferox & Thangjing & 4 & 4 & 2 & 4 & 14 \\
\hline $\begin{array}{l}\text { Hedychium } \\
\text { coronarium }\end{array}$ & Loklei & 4 & 4 & 3 & 4 & 15 \\
\hline $\begin{array}{l}\text { Hedyotis } \\
\text { auricularia }\end{array}$ & Langban-koukha & 1 & 1 & 3 & 1 & 6 \\
\hline $\begin{array}{l}\text { Houttuynia } \\
\text { cordata }\end{array}$ & Toningkhok & 4 & 4 & 3 & 3 & 14 \\
\hline $\begin{array}{l}\text { Hydrocotyle } \\
\text { sibthorpioides }\end{array}$ & Lei/Lai-peruk & 1 & 1 & 2 & 2 & 6 \\
\hline Ipomea aquatica & Kolamni & 3 & 3 & 3 & 2 & 11 \\
\hline Jussiaea repens & Ising kundo & 1 & 1 & 3 & 1 & 6 \\
\hline Leucas aspera & Mayang lembum & 1 & 1 & 3 & 1 & 6 \\
\hline Marsilea minuta & Ishing-yensang & 1 & 1 & 4 & 1 & 7 \\
\hline $\begin{array}{l}\text { Nasturtium } \\
\text { indicum }\end{array}$ & Uchi-hangam & 1 & 1 & 3 & 1 & 6 \\
\hline Nelumbo nucifera & Thambal & 3 & 4 & 3 & 4 & 16 \\
\hline $\begin{array}{l}\text { Neptunia } \\
\text { oleraceae }\end{array}$ & Eshing ikaithabi & 4 & 4 & 2 & 4 & 14 \\
\hline Nymphaea stellata & Thariktha & 2 & 2 & 2 & 2 & 8 \\
\hline $\begin{array}{l}\text { Nymphoides } \\
\text { indicum }\end{array}$ & Tharo-macha & 2 & 2 & 2 & 2 & 8 \\
\hline Oenanthe javanica & Komprek & 4 & 4 & 2 & 3 & 13 \\
\hline Plantago erosa & Yempat & 1 & 1 & 3 & 1 & 6 \\
\hline $\begin{array}{l}\text { Polygonum } \\
\text { barbatum }\end{array}$ & Yelang & 3 & 3 & 2 & 3 & 11 \\
\hline $\begin{array}{l}\text { Polygonum } \\
\text { perfoliatum }\end{array}$ & Lilhar & 1 & 1 & 3 & 1 & 6 \\
\hline $\begin{array}{l}\text { Polygonum } \\
\text { posumba }\end{array}$ & Phakpai & 3 & 3 & 2 & 3 & 11 \\
\hline $\begin{array}{l}\text { Ranunculus } \\
\text { scleratus }\end{array}$ & Kakyel-khujil & 1 & 1 & 2 & 1 & 5 \\
\hline $\begin{array}{l}\text { Sagittaria } \\
\text { sagittifolia }\end{array}$ & Koukha & 3 & 4 & 2 & 3 & 12 \\
\hline Trapa natans & Heikak yetli & 3 & 4 & 2 & 3 & 12 \\
\hline Zizania latifolia & Eshing kambong & 3 & 4 & 3 & 4 & 14 \\
\hline
\end{tabular}

* The status of species in each category is rank in a scale of 4 to1 (Use and Taste status: 4-most preferred, 3commonly preferred, 2-preferred but not so common, and 1-occassionally used; Availability status: 4-extensively available, 3-commonly available, 2-available but not so common, and 1-rare; Conservation status: 4-widely required, 3-normally required, 2-required but not so common, 1-not required at present). 
Figures

\section{$\%$ of marketable and non marketable plant}

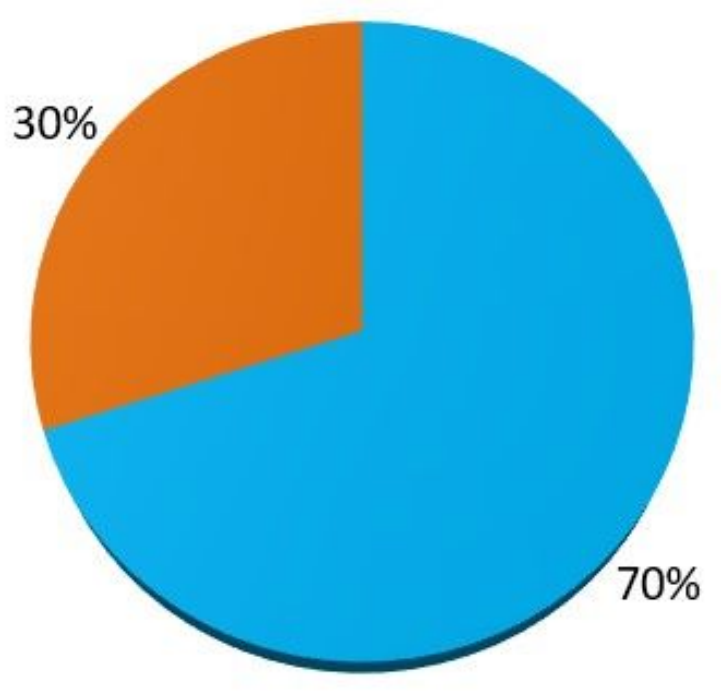

marketable

non marketable

Figure 1

Graphical representation of marketable and non-marketable of aquatic plants 


\section{$\%$ of plant parts used}

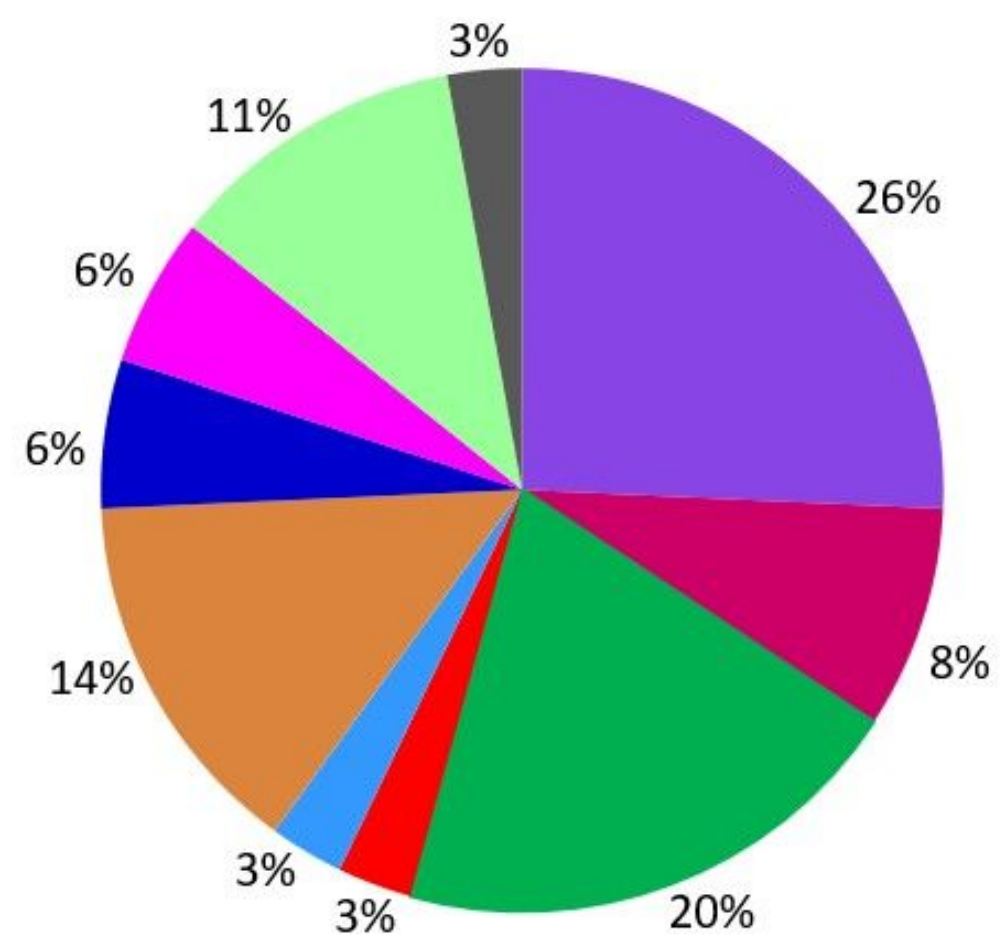

- leaves

roots

ahoots

a stem

n flower

nhizome

a fruits

n seeds

whole

plant

Figure 2

Graphical presentation of plant parts used 

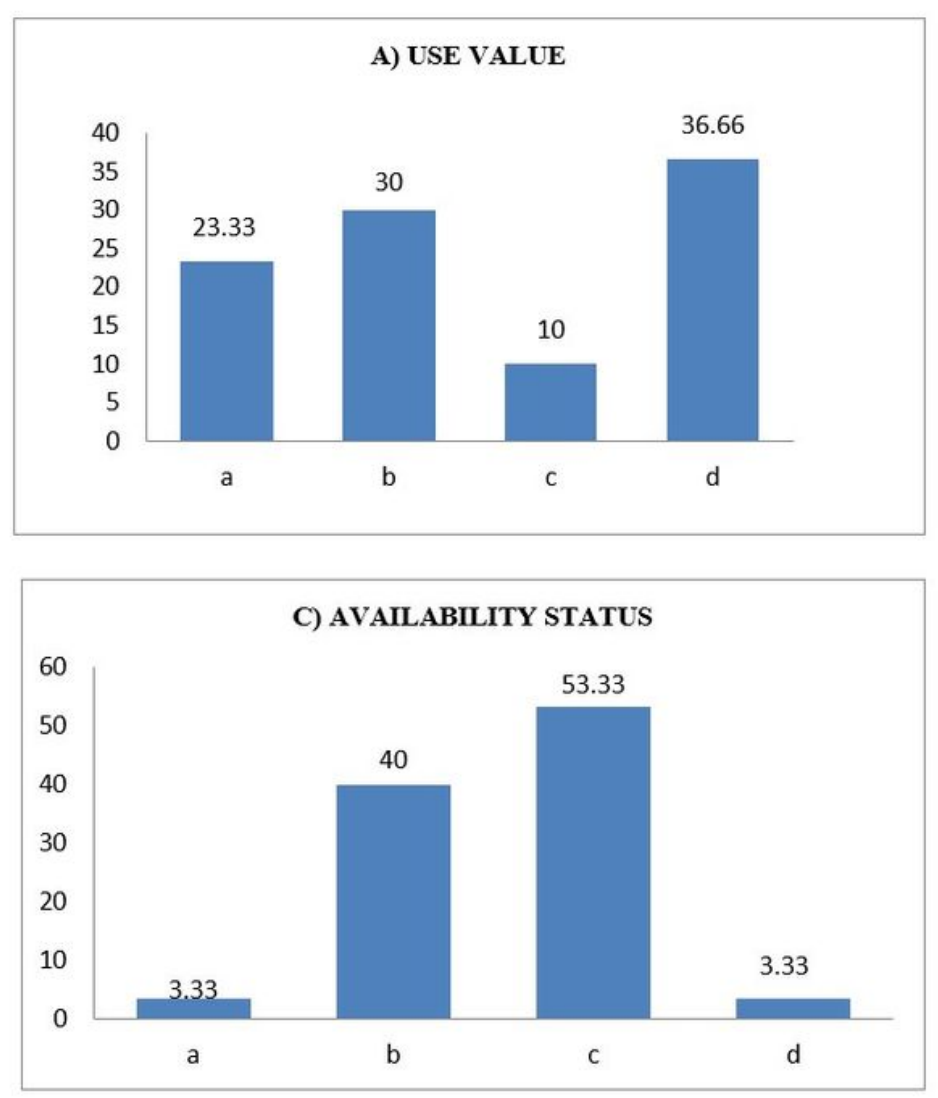
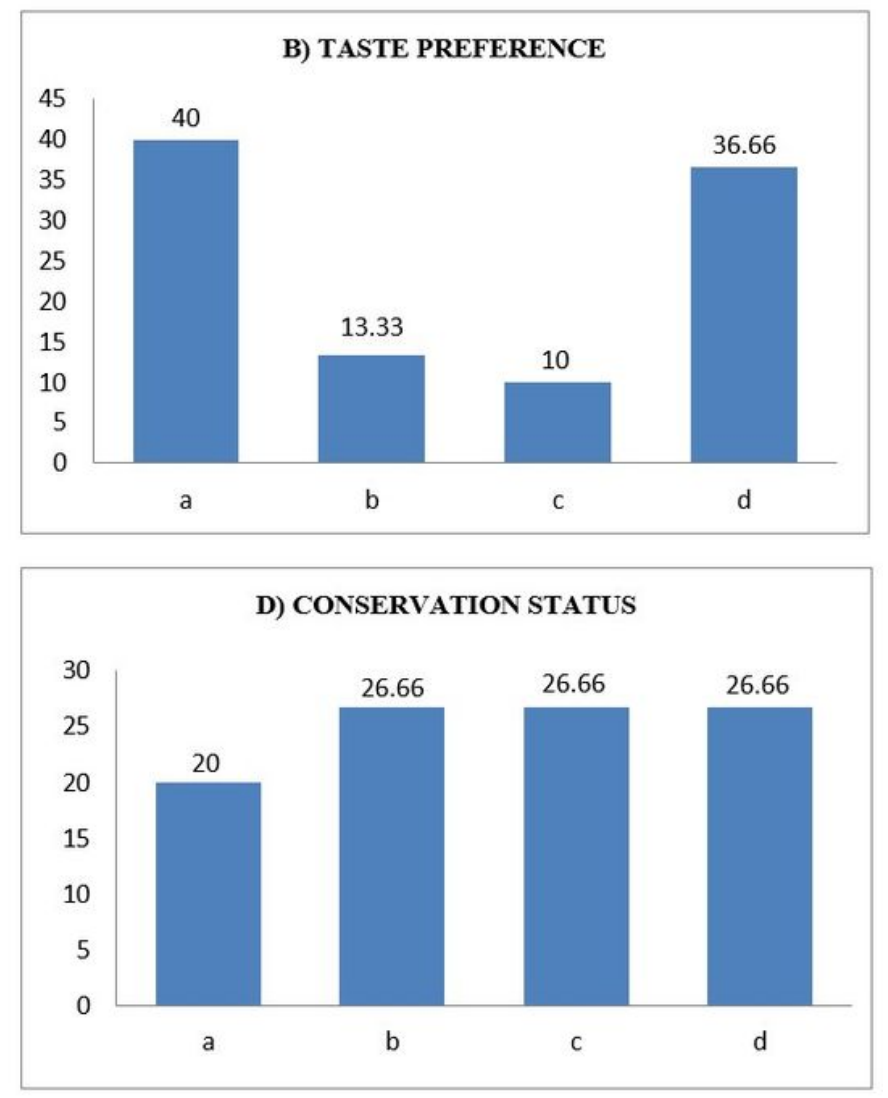

Figure 3

Bar diagram showing percent Use value (A), Taste preference (B), Availability status (C) and Conservation status (D) of aquatic plants in Manipur, India (ranking for 'Use' and 'Taste' status comprised as: (a) occasionally used, (b) preferred but not so common, (c) commonly preferred, and (d) most preferred; for 'Availability' status: (a)- rare, (b) available but not so common, (c) commonly available, and (d) extensively available; and for 'Conservation' status: (a) no conservation required at present, (b) conservation required but not so urgent, (c) conservation urgently required, and (d) conservation highly required).

\section{Image not available with this version}

Figure 4

This image is not available with this version. 


\section{Collection of the plant leaves/fruits}

Selection of the tender leaves/ripe fruits

Removal of the infested and diseased portion

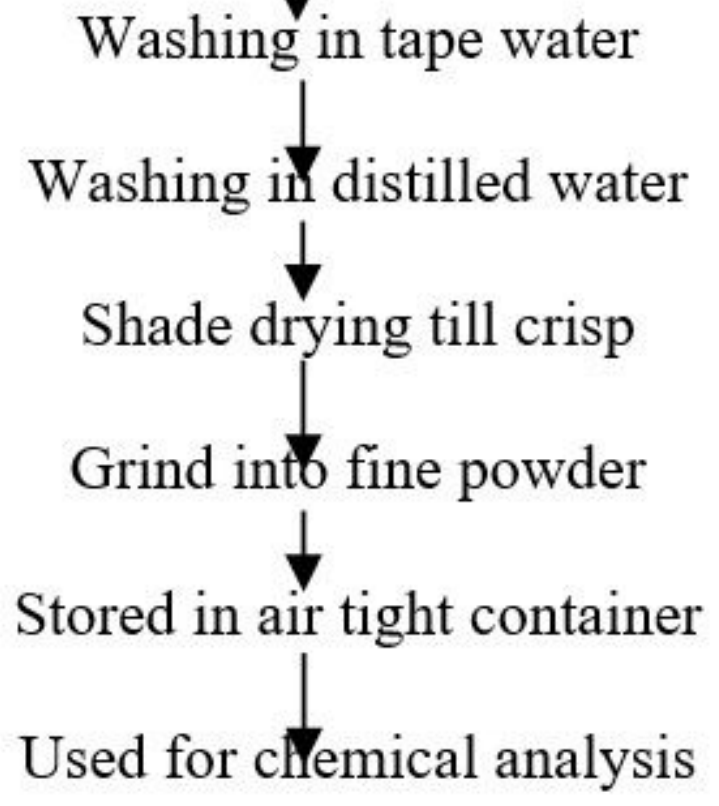

Figure 5

Flow diagram for preparation of samples (who, 2003) 